\title{
Celecoxib alleviates tamoxifen-instigated angiogenic effects by ROS-dependent VEGF/ VEGFR2 autocrine signaling
}

B N Prashanth Kumar ${ }^{1}$, Shashi Rajput ${ }^{1}$, Kaushik Kumar Dey ${ }^{1}$, Aditya Parekh', Subhasis Das ${ }^{1}$, Abhijit Mazumdar $^{2}$ and Mahitosh Mandal ${ }^{1 *}$

\begin{abstract}
Background: Tamoxifen (TAM) is widely used in the chemotherapy of breast cancer and as a preventive agent against recurrence after surgery. However, extended TAM administration for breast cancer induces increased VEGF levels in patients, promoting new blood vessel formation and thereby limiting its efficacy. Celecoxib (CXB), a selective COX-2 inhibitor, suppresses VEGF gene expression by targeting the VEGF promoter responsible for its inhibitory effect. For this study, we had selected CXB as non-steroidal anti-inflammatory drug in combination with TAM for suppressing VEGF expression and simultaneously reducing doses of both the drugs.

Methods: The effects of CXB combined with TAM were examined in two human breast cancer cell lines in culture, MCF7 and MDA-MB-231. Assays of proliferation, apoptosis, angiogenesis, metastasis, cell cycle distribution, and receptor signaling were performed.

Results: Here, we elucidated how the combination of TAM and CXB at nontoxic doses exerts anti-angiogenic effects by specifically targeting VEGFNEGFR2 autocrine signaling through ROS generation. At the molecular level, TAM-CXB suppresses VHL-mediated HIF-1a activation, responsible for expression of COX-2, MMP-2 and VEGF. Besides low VEGF levels, TAM-CXB also suppresses VEGFR2 expression, confirmed through quantifying secreted VEGF levels, luciferase and RT-PCR studies. Interestingly, we observed that TAM-CXB was effective in blocking VEGFR2 promoter induced expression and further 2 fold decrease in VEGF levels was observed in combination than TAM alone in both cell lines. Secondly, TAM-CXB regulated VEGFR2 inhibits Src expression, responsible for tumor progression and metastasis. FACS and in vivo enzymatic studies showed significant increase in the reactive oxygen species upon TAM-CXB treatment.

Conclusions: Taken together, our experimental results indicate that this additive combination shows promising outcome in anti-metastatic and apoptotic studies. In a line, our preclinical studies evidenced that this additive combination of TAM and CXB is a potential drug candidate for treatment of breast tumors expressing high levels of VEGF and VEGFR2. This ingenious combination might be a better tailored clinical regimen than TAM alone for breast cancer treatment.
\end{abstract}

\footnotetext{
* Correspondence: mahitosh@smst.iitkgp.ernet.in

${ }^{1}$ School of Medical Science and Technology; Indian Institute of Technology Kharagpur, Kharagpur-721302, West Bengal PIN-721302, India

Full list of author information is available at the end of the article
} 


\section{Background}

Extensive clinical studies over the past 30 years have shown that tamoxifen (TAM) can reduce the incidence and regression of breast carcinoma among women worldwide. A selective estrogen receptor (ER) modulator, TAM has been used extensively in the clinical management of primary and advanced breast cancer and is also widely employed as a preventive agent after surgery for breast cancer [1]. High survival rates for patients with early breast cancer as well as improved quality of life for patients with metastatic disease are observed in patients administered TAM. It also reduces the incidence of breast cancer in patients at risk for developing the disease and also the recurrence in women with ductal carcinoma in situ [2]. The constitutive therapeutic efficacy of TAM is due to its anti-proliferative action of binding competitively to ER, thereby blocking the mitogenic effect of estradiol [3].

Angiogenesis, a major attribute of tumorigenesis, provides a tumor with oxygen and nutrients [4,5]. Several different growth factors and cytokines drive angiogenesis such as VEGF, a predominant pro-angiogenic factor in human cancer [6,7]. Conventionally, stimulated VEGF bind to VEGF receptor 2 (VEGFR2) in tumors, contributing to the proliferation, migration and invasion of breast cancer cells. On ligand interaction, VEGFR2 is activated through receptor dimerization and autophosphorylation of tyrosine residues (Y951, Y1175, and Y1214) in its cytoplasmic kinase domain. VEGF expression may be conducive to the aggressive phenotype seen in HER2positive breast cancer. However, VEGF is also expressed in a considerable number of HER2-negative tumors, suggesting that its expression is regulated by additional processes in breast cancer. VEGF and VEGFR2 are coexpressed in several epithelial tumors, including breast cancer, which provides further evidence for an autocrine pathway for this ligand and its receptor [8]. A relatively high cytosolic level of VEGF in breast cancer cells has been associated with the clinical aggressiveness and relapse of the cancer [9]. However, TAM is also known to increase the expression of vascular endothelial growth factor (VEGF), which is an undesirable effect in breast cancer treatment $[10,11]$. TAM can exert estrogen-like agonistic effects, such as induction of VEGF mRNA expression in MCF7 breast cancer cells [12-14]. Specifically, VEGF is one of the gene induced by both TAM and estrogen in rat uterine cells [15]. An elevated cytosolic level of the ligand VEGF has been associated with inferior outcome in non-randomized trials of TAM-treated hormone-responsive patients, indicating that VEGF can be a marker of response for endocrine therapy [16]. VEGF is a predictor of TAM response among ERpositive patients with either a low or high fraction of ER-positive cells [14]. VEGFR2 is an additional predictor of TAM response, with a more notable effect in ERpositive tumors. The expression levels of VEGFR2 and VEGF affect the efficacy of TAM in breast cancer patients [8]. Furthermore, adjuvant TAM administration results in shorter survival of breast cancer patients who have higher expression levels of VEGF or VEGFR2 [16]. From the above reports, we interpret that reduction in TAM dose can decrease the VEGF production. This reduction in TAM dose can be achieved by employing combination therapy.

The combination of TAM and an anti-VEGF signaling agent inhibits both ER-mediated signaling and VEGFstimulated stromal activation, thereby reducing angiogenesis $[8,17]$. Studies have so far indicated that, in human breast cancers, COX-2 overexpression is correlated with induction of VEGF expression and therefore tumor angiogenesis [18]. Inhibition of COX-2 by non-steroidal antiinflammatory drugs leads to restricted angiogenesis and down-regulates production of VEGF [19]. In pancreatic cancer, celecoxib (CXB), a selective COX-2 inhibitor, suppresses VEGF gene expression by targeting the VEGF promoter responsible for its inhibitory effect [20]. In this context, for this study we had selected CXB as nonsteroidal anti-inflammatory drug in combination with TAM for suppressing VEGF expression and simultaneously reducing doses of both the drugs.

The objective of the current study was to evaluate the potency of CXB in combination with TAM in inhibiting breast cancer cell growth, proliferation, and angiogenesis and reveal the underlying molecular mechanisms involved in TAM-induced apoptosis. We also determined whether $\mathrm{CXB}$, as an adjuvant agent, could reduce the dosage of TAM and its consequences in potentially reducing VEGF- and VEGFR2-mediated insensitivity in breast cancer cells to TAM.

\section{Methods \\ Cell Lines}

Human breast cancer cell lines MCF7, MDA-MB-231, MDA-MB-468, T-47D, and normal cell lines NIH/3T3 and $\mathrm{HaCaT}$ were obtained from the National Centre for Cell Science (Pune, India) and cultured. Cells were incubated at $37^{\circ} \mathrm{C}$ in a $5 \% \mathrm{CO}_{2}$ atmosphere and at $95 \%$ humidity.

\section{Reagents}

Stock solutions of $10 \mathrm{mM}$ TAM and $1 \mathrm{mM}$ CXB (Sigma Aldrich, St. Louis, MO, USA) were dissolved in dimethyl sulfoxide (Sigma Aldrich, St. Louis, MO, USA), stored at $-20^{\circ} \mathrm{C}$, and diluted in fresh medium just before use. For western blot analysis, the following antibodies were used: rabbit monoclonal anti-Bak, anti-CBP, anti-p-MAPK (Thr202/Tyr204), anti-MAPK, anti-p-Akt (Ser473), antiAkt, anti-p-STAT3 (Tyr705), anti-STAT3, anti-p-Src 
(Tyr416), anti-Src, anti-p-VEGFR2 (Tyr1175), antiVEGFR2, anti-p-BAD (Ser136), anti-BAD, anti-COX-2, anti-HIF $\alpha$, anti-MMP-2, anti-VHL, and anti-PARP (all Cell Signalling Technology, Beverly, MA, USA), mouse monoclonal anti- $\beta$-Actin (Sigma Aldrich, St. Louis, MO, USA), and mouse monoclonal anti-Bcl2, mouse monoclonal anti-Bax, and horseradish peroxidase-conjugated goat anti-rabbit IgG and anti-mouse IgG (Santa Cruz Biotechnology, Santa Cruz, CA, USA). The pGL3VEGFR2-780 plasmid (Addgene plasmid 21307) was kindly provided by Dr. Donald Ingber (Harvard Medical School, Boston, MA, USA), and the pGL3-Basic plasmid was purchased from Promega (Madison, WI, USA). FuGENE HD transfection reagent was purchased from Roche Applied Science (Mannheim, Germany); OptiMEM I reduced serum medium, TRIzol reagent kit and Coomassie Blue R-250 from Gibco-BRL, Invitrogen Corporation, Carlsbad, CA, USA; Nonidet P-40 lysis buffer, chemiluminescent peroxidase substrate, propidium iodide (PI), 4' ,6-diamidino-2-phenylindole (DAPI), 3-(4,5dimethylthiazol-2-yl)-2,5 diphenyltetrazolium bromide (MTT), and sense and antisense VEGFR2 oligo primers from Sigma Aldrich, St. Louis, MO, USA; and pyrogallol and $\mathrm{H}_{2} \mathrm{O}_{2}$ from Merck (Whitehouse Station, NJ, USA). Stock solutions of PI, DAPI, and MTT were prepared by dissolving $1 \mathrm{mg}$ of each compound in $1 \mathrm{ml}$ of phosphatebuffered saline (PBS). The solution was protected from light, stored at $4^{\circ} \mathrm{C}$, and used within 1 month. Stock concentrations of $10 \mathrm{mg} / \mathrm{ml}$ RNaseA (Sigma Aldrich, St. Louis, MO, USA) were prepared and kept at $-20^{\circ} \mathrm{C}$.

\section{Cell viability assay}

MCF7 and MDA-MB-231 cells grown in monolayers were harvested and dispensed in 96 well culture plates in $100 \mu \mathrm{l}$ of Dulbecco's Modified Eagle's Medium (DMEM) at a concentration of $5 \times 10^{3}$ cells per well. After $24 \mathrm{~h}$, differential drug concentrations of TAM $(0-40 \mu \mathrm{M})$, CXB $(0-250 \mu \mathrm{M})$, or both $(0-5 \mu \mathrm{M}$ TAM plus $30 \mu \mathrm{M}$ $\mathrm{CXB}$ ) were added to the cells. Cell viability was measured after $48 \mathrm{~h}$ of incubation using the MTT colorimetric assay at $540 \mathrm{~nm}$ with slight modifications to the protocol [21]. The dose-effect curves were analyzed using Prism software (GraphPad Prism, CA, USA).

\section{Cell cycle analysis}

To determine the cell cycle distribution, $5 \times 10^{5}$ MCF7 or MDA-MB-231 cells were plated in 60-mm dishes and treated with their respective half maximal inhibitory concentration $\left(\mathrm{IC}_{50}\right)$ values of TAM, CXB, or both for $48 \mathrm{~h}$. After treatment, the cells were collected by trypsinization, fixed in $70 \%$ ethanol, and kept at $-20^{\circ} \mathrm{C}$ overnight for fixation. Cells were washed in PBS, resuspended in $1 \mathrm{~mL}$ of PBS containing $100 \mu \mathrm{g} / \mathrm{mL}$ RNase and $40 \mu \mathrm{g} / \mathrm{mL}$ PI incubated in the dark for $30 \mathrm{~min}$ at room temperature [22-24].
The distribution of cells in the cell-cycle phases were analyzed from the DNA histogram using a FACS Caliber flow cytometer (Becton-Dickinson, San Jose, CA, USA) and CellQuest software (CA, USA).

\section{Wound-closure assay}

To assess the effect of TAM and CXB on cell migration, MCF7 and MDA-MB-231 cells $\left(1 \times 10^{5}\right)$ were plated in 12 -well plates in complete growth medium [23,25]. After $24 \mathrm{~h}$ of growth, a scratch was made through the confluent cell monolayer using a $200-\mu \mathrm{l}$ pipette tip, and the cells were treated with the $\mathrm{IC}_{50}$ values of TAM, CXB, or both in $3 \mathrm{ml}$ of complete medium. At $48 \mathrm{~h}$ posttreatment, cells were stained with hematoxylin and eosin. Cells invading the wound line were observed under an inverted phase-contrast microscope using $20 \times$, Leica DMR, Germany. The distance between the two sides of the scratch was measured after the indicated time intervals using Leica QWin software, IL, USA. Each experiment was performed three times with triplicate samples.

\section{Boyden chamber assay}

To test the anti-invasive effect of TAM and CXB, 8- $\mu \mathrm{m}$ filters were coated with Matrigel $(20 \mu \mathrm{g}$ per filter) and placed in Boyden chambers. MDA-MB-231 cells $(1 \times$ $10^{5}$ ) suspended in DMEM containing $0.1 \%$ bovine serum albumin and treated with $\mathrm{IC}_{50}$ of TAM, CXB, or both, were added to the top chamber. Conditioned medium from mouse fibroblast NIH/3T3 cells was used as a source of chemoattractant and placed in the bottom compartment of the chamber [26]. After $24 \mathrm{~h}$ incubation at $37^{\circ} \mathrm{C}$ in a $5 \% \mathrm{CO}_{2}$ atmosphere, cells that migrated to the lower surface of filters were detected with traditional staining with hematoxylin and eosin. Cells were counted in five fields of each well under inverted phase-contrast microscope using 20×, Leica DMR, Germany.

\section{Gelatin zymography}

Supernatants from MCF7 and MDA-MB-231 cells $(5 \times$ $10^{4}$ cells per well, six wells per plate) treated with TAM, $\mathrm{CXB}$, or both for $48 \mathrm{~h}$ were collected for matrix metalloproteinase (MMP) activity analysis by sodium dodecyl sulfate-polyacrylamide gel electrophoresis under non-reducing conditions. A total of $1.2 \mathrm{mg} / \mathrm{ml}$ gelatin was prepolymerized on a $10 \%$ polyacrylamide gel as a substrate. Electrophoresis was carried out at $4^{\circ} \mathrm{C}$. The gel was washed with renaturation buffer (50 mM Tris$\mathrm{HCl}, \mathrm{pH} 7.5,100 \mathrm{mM} \mathrm{NaCl}$, and 2.5\% Triton X-100), which was followed by incubation with a developing buffer $(50 \mathrm{mM}$ Tris-HCl, pH 7.5, $150 \mathrm{mM} \mathrm{NaCl}, 10 \mathrm{mM}$ $\mathrm{CaCl}_{2}, 0.02 \% \mathrm{NaN}_{3}$, and $1 \mu \mathrm{M} \mathrm{ZnCl}_{2}$ ) at $37^{\circ} \mathrm{C}$ for $16 \mathrm{~h}$ and staining with Coomassie Blue R-250, as described previously [27]. The stained bands are observed through 
a gel doc system (Bio-Rad). Densitometric analysis of stained bands was performed by ImageMaster 2D Platinum 7.0 Software (GE Healthcare Life Sciences, NJ, USA).

\section{Chorioallantoic Membrane (CAM) assay}

To determine the in vivo anti-angiogenic activity of TAM and CXB, a CAM assay was performed as described previously with some modifications [28]. Two day-old fertilized eggs were incubated at $37^{\circ} \mathrm{C}$ in $60-70 \%$ relative humidity. After $5 \mathrm{~d}$ of incubation, a $1-$ to $2-\mathrm{cm}^{2}$ window was opened and a sterile round filter paper (5$\mathrm{mm}$ in diameter; Whatman qualitative filter papers, Sigma-Aldrich, St. Louis, MO, USA) containing serumfree medium alone or supplemented with VEGF, TAM, $\mathrm{CXB}$, or both TAM and $\mathrm{CXB}$ (at $\mathrm{IC}_{50}$ concentrations) was applied onto the CAM of each embryo. After $2 \mathrm{~d}$ of incubation, the upper eggshell was removed, and capillaries within $2.5 \mathrm{~mm}$ around the filter paper were observed and photographed under a stereomicroscope (Olympus, SZX16, USA). Neovascularization around the disk was quantitated by determining the number of angiogenic vessels within the CAM around the disk.

\section{Capillary-like tube formation (HUVEC) assay}

For the capillary-like tube formation assay, growth factor-depleted Matrigel from BD Pharmingen, San Jose, CA, USA was applied to a 96-well tissue culture plate (50 $\mu \mathrm{l}$ per well). After polymerization of the Matrigel at $37^{\circ} \mathrm{C}$ for $1 \mathrm{~h}$, human umbilical vein endothelial cells (HUVECs) (Gibco-BRL, Invitrogen Corporation, Carlsbad, CA, USA) starved of serum for $2 \mathrm{~h}$ were harvested by using trypsin/EDTA, washed with assay medium, and seeded at a density of $7.5 \times 10^{3}$ cells per well (final volume $500 \mu \mathrm{l})$ on the polymerized Matrigel in the presence or absence of $30 \mathrm{ng} / \mathrm{ml}$ VEGF along with TAM, CXB, or both $[29,30]$. Plate was incubated at $37^{\circ} \mathrm{C}, 5 \% \mathrm{CO}_{2}$ for $24 \mathrm{~h}$, then the medium was aspirated and cells were fixed in $10 \%$ neutral buffered formalin. Tube formation was observed for $24 \mathrm{~h}$, representative pictures were taken at $10 \times$ magnifications under a stereomicroscope (Olympus, SZX16, USA) and tubes were counted in five random fields.

\section{Western blotting analysis}

For phosphoprotein studies, MCF7 and MDA-MB-231 cells $\left(1 \times 10^{6}\right.$ cells per $100 \mathrm{~mm}$ plate) were treated with TAM, CXB, or both at their respective $\mathrm{IC}_{50}$ doses for $24 \mathrm{~h}$. Cells in control wells were treated with $0.1 \%$ dimethyl sulfoxide for $1 \mathrm{~h}$. All cells were activated with recombinant human epidermal growth factor $(25 \mathrm{ng} / \mathrm{mL})$ for $30 \mathrm{~min}$. The cells were then scraped and lysed in Nonidet P-40 lysis buffer. Cell extracts (50 $\mu$ g of protein) were separated on a sodium dodecyl sulfate-polyacrylamide electrophoretic gel and transferred to nitrocellulose membranes, which were blocked in 3\% bovine serum albumin for $2 \mathrm{~h}$. After blocking, the membranes were incubated with primary antibodies overnight at $4^{\circ} \mathrm{C}$ and then with horseradish peroxidase-conjugated secondary antibody for $2 \mathrm{~h}$ at room temperature [24]. Proteins were visualized by exposing the chemiluminescence substrate (Sigma) to X-OMAT AR autoradiography film (Eastman Kodak, Rochester, NY, USA).

\section{Transfection studies}

MCF7 and MDA-MB-231 cells were plated in 60-mm petri dishes at a density of more than $4 \times 10^{5}$ per plate in DMEM supplemented with $10 \%$ fetal bovine serum. After being allowed to grow for $16-20 \mathrm{~h}$, cells were starved for $6 \mathrm{~h}$ with $2 \%$ fetal bovine serum. Confluent cells $(70-80 \%)$ were transiently transfected with $5 \mu \mathrm{g}$ of pGL3-VEGFR2-780 plasmid with $7.5 \mu \mathrm{l}$ of FuGENE HD transfection reagent in $100 \mu \mathrm{l}$ of Opti-MEM I reduced serum medium according to the manufacturer's protocol (Roche Diagnostics, Mannheim, Germany) [31]. After $24 \mathrm{~h}$ of transfection, the mix was replaced with complete medium containing TAM, CXB, both, or neither for $24 \mathrm{~h}$ and then lysed in luciferase lysis buffer (Sigma) [32,33]. Luciferase activity was measured with a luminometer (Varian cary eclipse, Palo Alto, CA, USA) and a luciferase assay kit (Sigma) and was normalized to $\beta$-galactosidase activity. All luciferase experiments were done in triplicate and repeated three times. Data is presented as means \pm SD.

\section{Measurement of VEGF levels}

To measure VEGF levels, MCF7 and MDA-MB-231 cells $\left(5 \times 10^{5}\right.$ cells per well, six wells per plate) were plated and incubated under culture conditions overnight, and the medium was replaced by serum-free culture conditioned medium. TAM, CXB, or both were added to the culture, and the medium was collected at $72 \mathrm{~h}$ [10]. VEGF levels were measured using a VEGF enzymelinked immunosorbent assay (ELISA) kit (DVE00, R\&D Systems, Minneapolis, MN, USA) according to the manufacturer's instructions. The optical density at $570 \mathrm{~nm}$ of each well was measured using an automated microplate reader (model 550, Bio-Rad, Hercules, CA, USA).

\section{Reverse transcription-polymerase chain reaction (RT-PCR)}

By using the TRIzol reagent kit, total RNA was extracted from MCF7 and MDA-MB-231 cells treated with TAM, CXB, or both. RT-PCR was run using a one-step RTPCR kit (Gibco-BRL, Invitrogen Corporation, Carlsbad, CA, USA). $\beta$-Actin was used as an internal control. The sense and antisense primers for the VEGFR2 gene were 5' -TGACCAACATGGAGTCGTG-3' and 5' -CCAGAG ATTCCATGCCACTT-3', respectively. The sense and 
antisense primers for $\beta$-Actin were $5^{\prime}$-TCATGTTTG

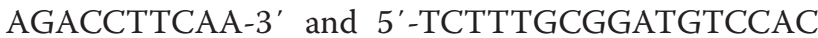
G-3', respectively. PCR was performed in a $25-\mu \mathrm{L}$ reaction volume. The cycling conditions were $94^{\circ} \mathrm{C}$ for $5 \mathrm{~min}$; 35 cycles of $94^{\circ} \mathrm{C}$ for $30 \mathrm{~s}, 54^{\circ} \mathrm{C}$ for $45 \mathrm{~s}$, and $72^{\circ} \mathrm{C}$ for $60 \mathrm{~s}$; and a final extension at $72^{\circ} \mathrm{C}$ for $10 \mathrm{~min}$. Amplified products were separated by $1.2 \%$ ethidium bromide-stained agarose gel electrophoresis and viewed under ultraviolet light. Electrophoresis photos were transferred to a computer and analyzed using the Gel Doc image system (BioRad) [34]. Semiquantitative analysis was performed by comparing the results of VEGFR2 mRNA with $\beta$-Actin.

\section{Animal studies}

Tumor response to CXB and TAM was studied using S180 tumor bearing female Swiss albino mouse model. Our study was approved by the Department of Biotechnology (DBT), INDIA under the project number: E-1/MMSMST/ 12, at Indian Institute of Technology Kharagpur, INDIA and the mice were maintained in accordance with the institute animal ethical committee (IAEC) guidelines approved by Indian Council of Medical Research (ICMR), New Delhi. The mice were housed and acclimatized in a pathogen-free environment at our institute's animal facility for 1 week prior to injection with mouse S180 sarcoma cells. Exponentially growing S180 cells were harvested and a tumorigenic dose of $2.5 \times 10^{6}$ cells was injected intraperitoneally into 6- to 7-week-old female Swiss albino mouse $[24,35,36]$. Tumors were allowed to grow in the mouse for $7 \mathrm{~d}$, when the animals were randomly assigned into one of four treatment groups (5 mice per group). The control group received $1 \%$ polysorbate resuspended in deionized water. The other three groups were treated with CXB (3.7 $\mathrm{mg} / \mathrm{kg}$ body weight), TAM ( $2 \mathrm{mg} / \mathrm{kg}$ body weight), or CXB plus TAM (2 and $1 \mathrm{mg} / \mathrm{kg}$ body weight, respectively) intraperitoneally on alternative days for 2 weeks. The doses were selected based on previous experiments [37,38]. Mouse body weight was measured before the treatment injections were given and on the $7^{\text {th }}$ and $14^{\text {th }}$ day of treatment. On $15^{\text {th }}$ day, the animals were euthanized using chloroform and their liver and kidney tissues were collected for enzymatic assays. Spleens were collected and cultured for a splenocyte surveillance study. Furthermore, S180 cells were collected from the site of treatment injections for in vivo and ex vivo cell cycle phase distribution studies.

\section{Assay of splenocyte proliferation}

Spleens from treated mice were collected, and single-cell spleen suspensions were pooled in serum-free DMEM by filtering the suspension through a sieve mesh with the aid of a glass homogenizer to exert gentle pressure on the spleen fragments. Samples were washed twice in PBS $0.1 \%(\mathrm{w} / \mathrm{v})$ bovine serum albumin. After centrifugation at
$200 \mathrm{~g}$ for $5 \mathrm{~min}$, the cells were placed into 96-well flatbottomed microplates in triplicate at $2.5 \times 10^{3}$ cells per well in DMEM supplemented with $10 \%$ fetal bovine serum. The cells were then incubated in a total volume of $100 \mu \mathrm{L}$ per well. Serum-free DMEM was used as control [39]. After $24 \mathrm{~h}$, cell proliferation was measured using the MTT assay.

\section{Measurement of antioxidative enzyme activity}

Parts of mouse liver and kidney tissues were homogenized in 0.1 M Tris buffer ( $\mathrm{pH} 7.0$ ), and the homogenate was centrifuged at $4000 \mathrm{~g}$ for $20 \mathrm{~min}$. The supernatant was immediately assayed for catalase (CAT) and superoxide dismutase (SOD). Determination of CAT activity was performed at room temperature in a $1-\mathrm{ml}$ mixture containing clear cell lysate, $100 \mathrm{mM}$ phosphate buffer (pH 7.0), and $10 \mathrm{mM}$ of $\mathrm{H}_{2} \mathrm{O}_{2}$ [40]. The decomposition of $\mathrm{H}_{2} \mathrm{O}_{2}$ is followed directly by a decrease in absorbance at $240 \mathrm{~nm}$ spectrophotometrically using Perkin Elmer Lambda45. CAT activity was expressed in micromoles of $\mathrm{H}_{2} \mathrm{O}_{2}$ consumed per minute per milligram of protein.

Total SOD was determined using the pyrogallol assay, based on the competition between pyrogallol oxidation by superoxide radicals and superoxide dismutation by SOD [41], and spectrophotometrically read at $420 \mathrm{~nm}$ using Perkin Elmer Lambda45. SOD activity was expressed in units per minute per milligram of protein.

\section{Measurement of ROS}

To measure intracellular reactive oxygen species (ROS), $10 \mu \mathrm{M} 2^{\prime}, 7^{\prime}$-dichlorofluorescein diacetate (DCFDA) was used [28]. MCF7 and MDA-MB-231 $\left(5 \times 10^{4}\right.$ cells per well, six wells per plate) were treated with $\mathrm{IC}_{50}$ of TAM, CXB, or both for $24 \mathrm{~h}$; washed with PBS; stained with DCFDA at a final concentration of $1 \mu \mathrm{g} / \mathrm{ml}$ for $30 \mathrm{~min}$ at $37^{\circ} \mathrm{C}$; and subjected to flow cytometry (FACS Calibur flow cytometer, Becton-Dickinson). Data were acquired and analyzed with CellQuest software.

\section{Statistical analysis}

All the statistical analysis was performed by Graphpad Prism 5 software. Data are presented using mean \pm S.D. The statistical significance was determined by using one-way analysis of variance (ANOVA). ${ }^{* * *} \mathrm{P}<0.001$ and ${ }^{* *} \mathrm{P}<0.05$ were considered significant.

\section{Results}

CXB enhances TAM-induced breast cancer cell death

To determine the effect of TAM, CXB, and both on the cell viability of breast cancer cells in vitro, ER- $\alpha$-positive MCF7 and T-47D cells and ER- $\alpha$-negative MDA-MB-231 and MDA-MB-468 cells were treated with increasing concentrations of CXB $(0-250 \mu \mathrm{M})$ or TAM $(0-40 \mu \mathrm{M})$. Treatment with TAM alone resulted in similar $\mathrm{IC}_{50}$ 
values for the MCF7, T-47D, MDA-MB-231, and MDAMB-468 cell lines $(9.06 \pm 0.29,8.99 \pm 0.55,13.05 \pm 0.91$, and $11.56 \pm 0.65 \mu \mathrm{M}$, respectively) (Figure $1 \mathrm{~A}$ ). Treatment with $\mathrm{CXB}$ alone also resulted in $\mathrm{IC}_{50}$ values that were similar in these four cell lines $(113.3 \pm 0.760,109.3 \pm$ $0.782, \quad 109.8 \pm 0.963$, and $121.7 \pm 0.240$, respectively) (Figure 1B). Combination treatment (0-5 $\mu \mathrm{M}$ TAM in the presence of $30 \mu \mathrm{M} C X B)$ resulted in a leftward shift of the concentration-response curve such that the $\mathrm{IC}_{50}$ values were reduced to $2.76 \pm 0.10,1.82 \pm 0.13,2.05 \pm 0.13$, and $2.86 \pm 0.12 \mu \mathrm{M}$, respectively (Figure $1 \mathrm{C}$ ), indicating that treatment with both agents was more cytotoxic than either one alone. The treatment regimens resulted in little toxicity in $\mathrm{NIH} / 3 \mathrm{~T} 3$ and $\mathrm{HaCaT}$ cell lines, demonstrating that TAM and CXB are non toxic to normal cell lines. Based on the results we have chosen respective $\mathrm{IC}_{50}$ 's of drugs for further treatments throughout the study.

\section{CXB enhances TAM-induced apoptosis and growth inhibition}

The effects of TAM and CXB on the cell cycles of MCF7 and MDA-MB-231 cells were then analyzed.
MCF7 cells ( $\mathrm{IC}_{50}$ values: $114 \mu \mathrm{M}$ CXB, $9 \mu \mathrm{M}$ TAM) treated with TAM or CXB had an increased percentage of apoptotic cells (i.e., cells in the sub- $G_{1}$ phase) compared with untreated cells (Figure 1D, top row). Similarly, MDA-MB-231 cells ( $\mathrm{IC}_{50}$ values: $110 \mu \mathrm{M}$ CXB, $13 \mu \mathrm{M}$ TAM) had an increased percentage of apoptotic cells compared with untreated cells (Figure 1D, bottom row). The low-dose combination (30 $\mu \mathrm{M}$ CXB plus $2 \mu \mathrm{M}$ TAM) resulted in an even greater percentage of apoptotic cells than the higher doses of either drug alone did. These data are consistent with the results from the MTT assay. Taken together, these results indicate an additive mechanism of TAM and CXB in inducing cell death through apoptosis.

\section{Effect of TAM and CXB on migration and invasion of breast cancer cells}

To ascertain the inhibitory effect of TAM and CXB on breast cancer metastasis, we used the wound-healing assay to investigate their effects on the migration potential of MCF7 and MDA-MB-231 cells. A wound through a confluent cell monolayer was created with a pipette

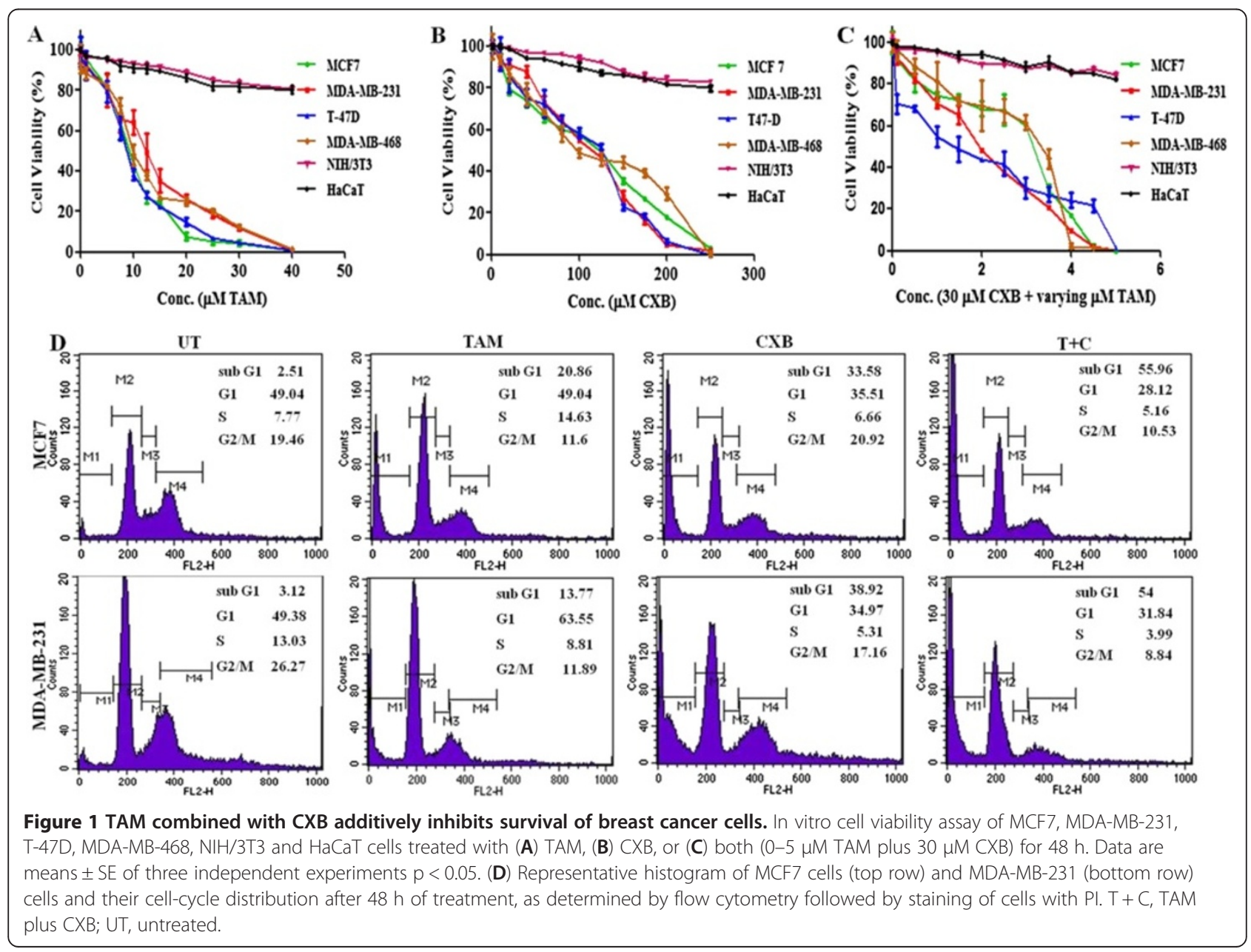


tip, and the migration of cells to fill up the wound was recorded by microscopic observation. After $48 \mathrm{~h}$, the wound had almost completely filled in the cleared region in untreated MCF7 and MDA-MB-231 cells (Figures 2A and $2 \mathrm{~B}$ ). The migration of MDA-MB-231 cells was reduced with TAM or CXB with respect to the untreated cells and greatly reduced when both TAM and CXB were used. However, TAM and CXB had limited effects in MCF7 cells, which might be explained by the poor invasiveness of this cell line.

The ability of TAM and CXB to reduce the invasiveness of MDA-MB-231 cells was further investigated by the Boyden chamber assay. Cells treated with $\mathrm{IC}_{50}$ concentrations of TAM, CXB, or both for $24 \mathrm{~h}$ were plated in the upper chamber, and the number of cells that moved to the underside of the coated membrane was counted $12 \mathrm{~h}$ later using a light microscope. The chambers were stained with hematoxylin and eosin and analyzed by photography. Again, compared with the results with either agent alone, the combination of TAM and CXB greatly inhibited MDA-MB-231 cell invasion (Figure 2C).
TAM and CXB inhibit activation of MMP-2 in breast cancer cell lines

Substantial levels of MMP secretion have been reported for metastatic breast cancer tumors and to be associated with the degradation of extraceullular matrix, a crucial step in metastasis [42]. Zymographic analyses showed that TAM and CXB additively inhibited MMP-2 activity in both MCF7 and MDA-MB-231 cells (Figure 2D). Thus, apart from its anti-VEGF effect in inhibiting tumor cells, this combination treatment can inhibit the metastasis and spread of breast cancer cells by reducing MMP-2. The addition of CXB enhanced the antimetastatic potential by more than 2 -fold in comparison to control. However, the impact of TAM and CXB on MMP9 activity is inconclusive because an extremely low level of MMP-9 was detected in untreated cells (data not shown).

\section{TAM and CXB inhibit in vivo angiogenesis and in vitro tube-like capillary formation}

The CAM model was used to investigate the effect of TAM and CXB on angiogenesis in vivo [43]. CAM assay with the PBS group did not show any notable avascular zone around
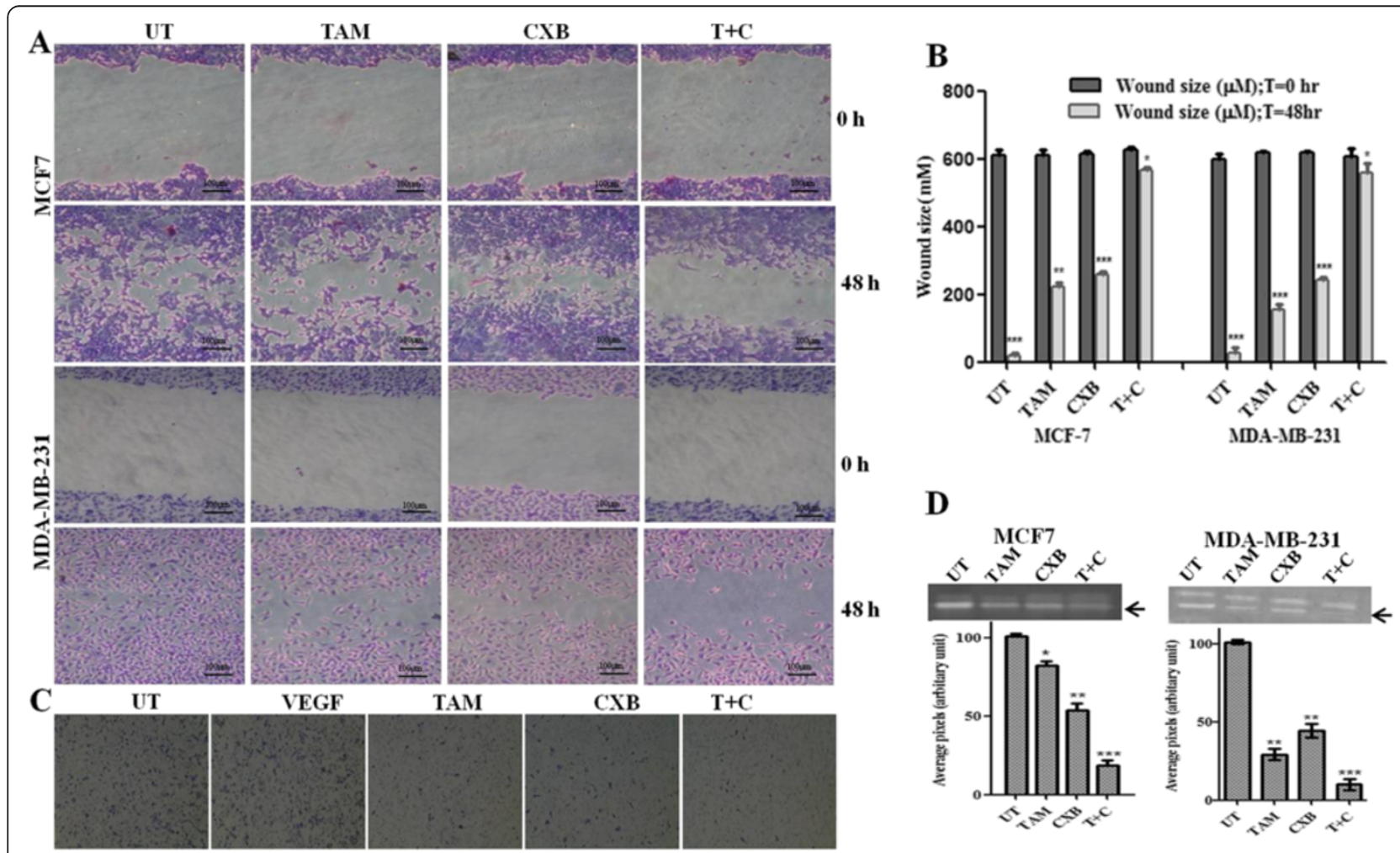

D

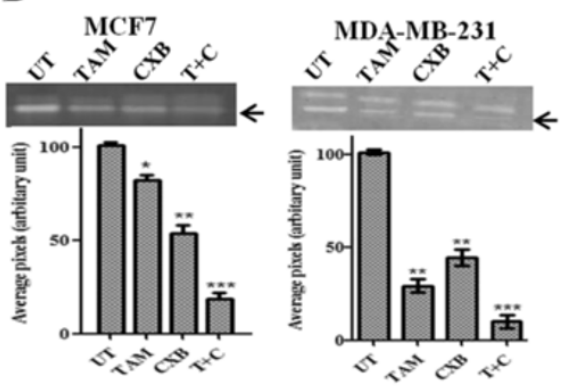

Figure 2 Anti-invasive and anti-migratory potential of TAM and CXB in MCF7 and MDA-MB-231 cells. (A) Representative hematoxylin- and eosin-stained cell images migrating into the wounded area in an in vitro wound healing assay at times $0 \mathrm{~h}$ and $48 \mathrm{~h}$. Scale bars, $100 \mu \mathrm{m}$. (B) Quantification of wound-healing results. Data are means \pm SE of three random widths along the wound. $P<0.05$. (C) Representative photomicrographs of Boyden chamber assays of MDA-MB-231 cell invasion through Matrigel. Cells were stained with hematoxylin- and eosin. (D) Top: Gelatinolytic activity of MMP-2 in MCF-7 cells and MDA-MB-231 cells treated for 48 h. Bottom: Densitometric analysis of MMP-2 protein levels in gelatin blot. Data are means \pm SE of three independent experiments. $P<0.05$ (t-test).T $+C$, TAM plus CXB; UT, untreated cells. 
the implanted filter paper (Figures $3 \mathrm{~A}$ and $3 \mathrm{C}$ ). In contrast, treatment with TAM, CXB, and both agents together inhibited the development of new embryonic capillaries and produced an avascular zone around the implanted filter papers. The inhibition of angiogenesis was most prominent when TAM and CXB were combined.

Next we performed tube formation assays with HUVECs, which are widely used as in vitro assays for angiogenesis. After $24 \mathrm{~h}, \mathrm{HUVEC}$ treated with PBS only rapidly aligned and formed hollow, tube-like structures, whereas HUVECs treated with both TAM and CXB showed a significant reduction of tube formation compared with TAM or CXB alone (Figures 3B and 3D). Collectively, these results suggest that $\mathrm{CXB}$ enhances the anti-angiogenic action of TAM by inhibiting HUVEC differentiation into tube-like structures during angiogenesis.

TAM and CXB inhibit angiogenesis via von Hippel-Lindau tumor suppressor protein (VHL)-mediated degradation of hypoxia-inducible factor $1 a$ (HIF-1a)

VHL regulates activated HIF- $1 \alpha$ through ubiqitination by prolyl hydroxylation under normoxia conditions [44].

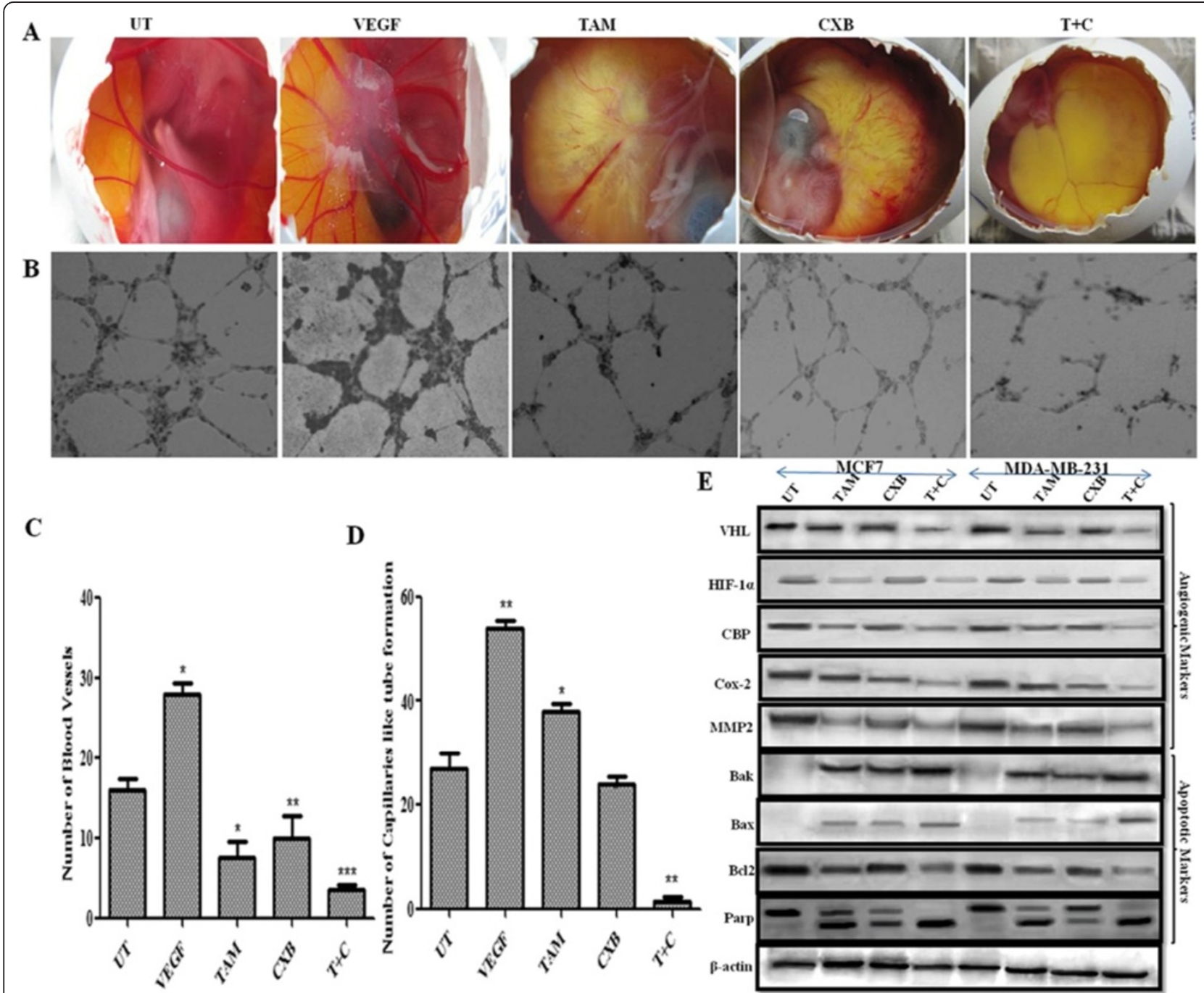

Figure 3 Anti-angiogenic and anti-tube formation potential of TAM and CXB. (A) In vivo CAM assay. CAMs were implanted with sponges loaded with serum-free medium alone or supplemented with vascular endothelial growth factor (VEGF), TAM, CXB, or TAM plus CXB.

(B) Inhibition of capillary-like tube formation in vitro (HUVECs assay). HUVECs were seeded $\left(7.5 \times 10^{3}\right.$ cells/well) into a 96-well tissue culture plate coated with $50 \mu \mathrm{l}$ Matrigel. Then, TAM and/or CXB were added. Cells were incubated in HUVEC growth medium in a $37^{\circ} \mathrm{C}, 5 \% \mathrm{CO}_{2}$ incubator. Tube formation was observed for $24 \mathrm{~h}$ and images were taken (magnification of 10x). (C) Number of blood vessels in CAM assay was counted as means \pm SD of blood vessel count for four independent experiments $P<0.05$. (D) Number of capillary-like structures in capillary-like tube formation assay was counted using light microscopy. Data are presented as means \pm SD of four independent experiments. (E) Western blotting analysis of apoptotic and angiogenic markers in MCF7 and MDA-MB-231 cells treated with TAM, CXB, or both. $\beta$-Actin was used as an invariant control for equal loading. Representative blots from three independent experiments are shown. T+C, TAM plus CXB; UT, untreated cells. 


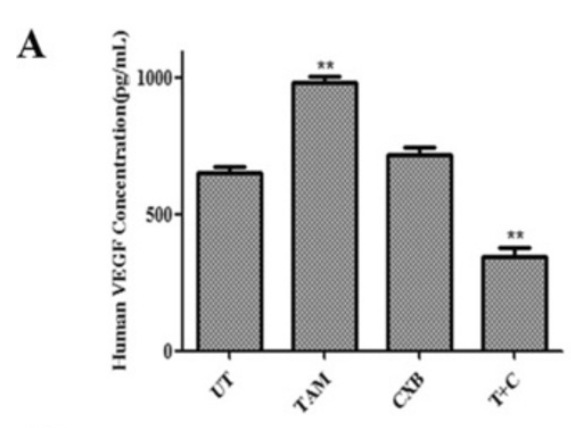

B

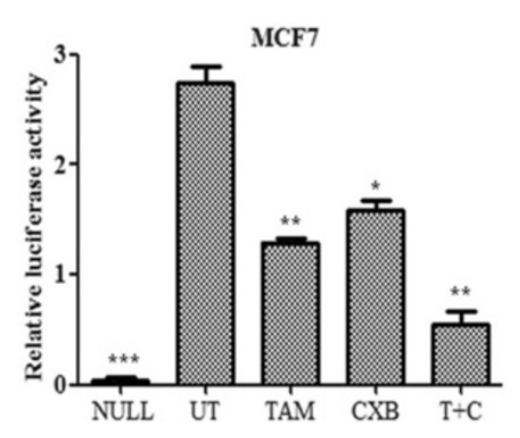

C
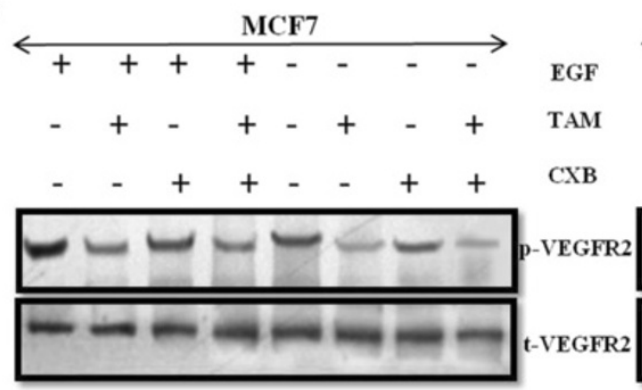

D

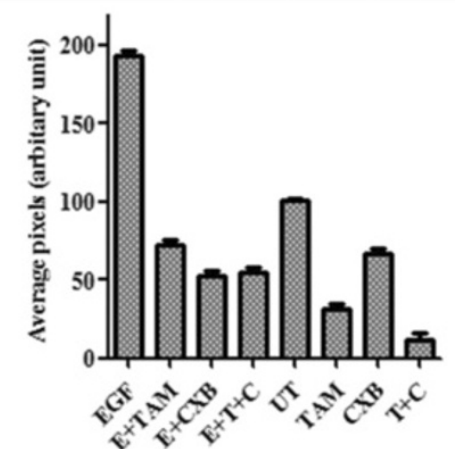

$\mathbf{E}$

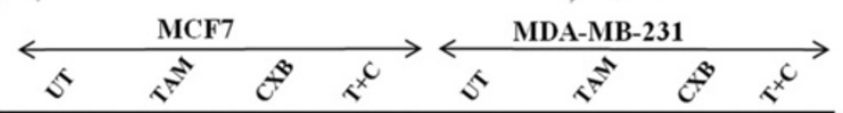

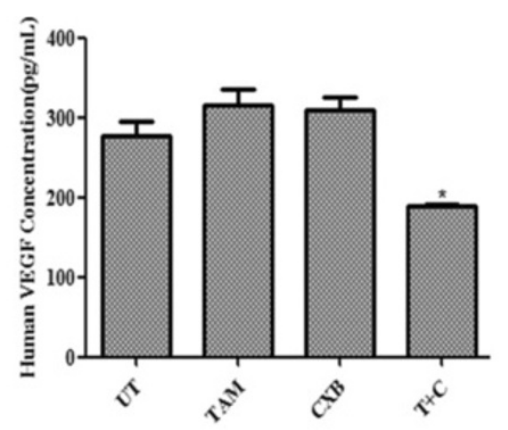
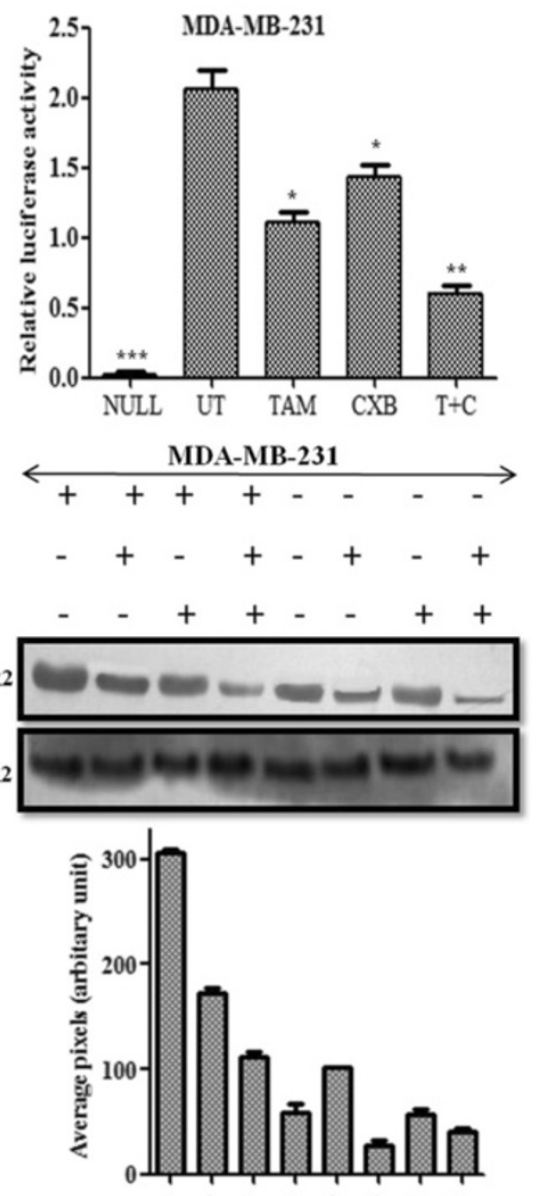

$$
\text { कि }
$$

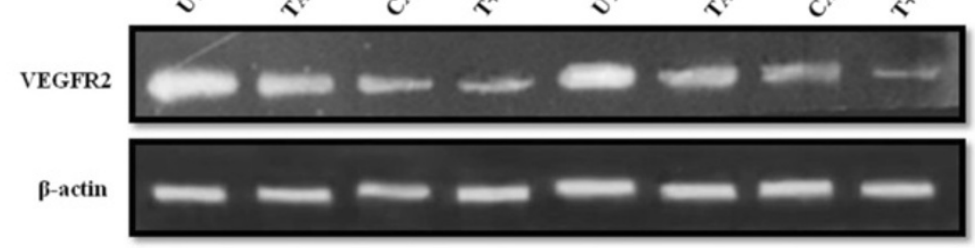

Figure 4 (See legend on next page.) 


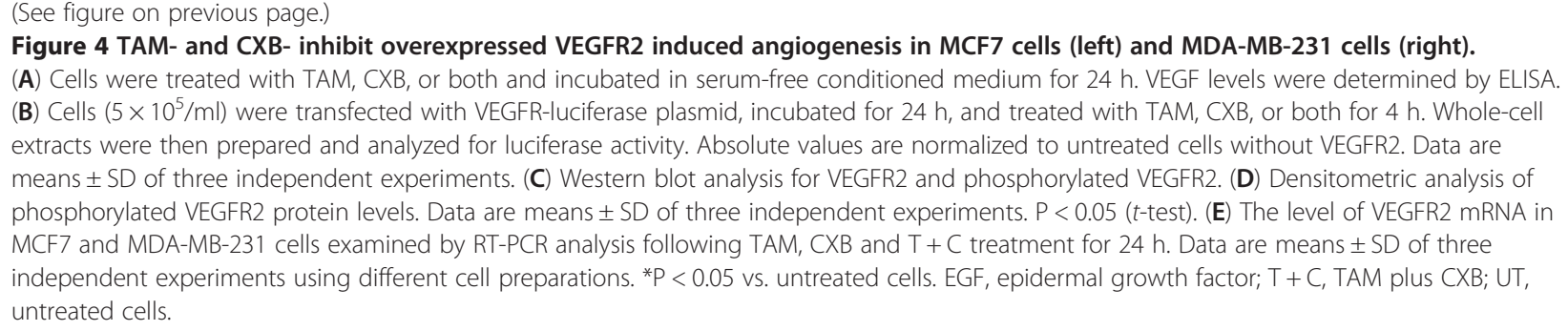

In reduced oxygen conditions, HIF- $1 \alpha$ binds to hypoxiaresponsive elements which, in turn, stimulate the transcriptional coactivators CREB-binding protein and induces transcription of various target genes involved in tumor invasion, cell survival, and angiogenesis. Apart from its role in angiogenesis, HIF- $1 \alpha$ promotes invasion by regulating the expression of COX-2, MMP-2, and other cytokines and growth factors [45]. Our western blotting results demonstrated that the combination of TAM and CXB modulated VHL expression in MCF7 and MDA-MB-231 cells, thus regulating HIF- $1 \alpha$, which in turn binds to CREBbinding protein, thereby altering the expression of the downstream effector molecules involved in metastasis and angiogenesis (e.g., MMP-2, COX-2 and VEGF) (Figure 3E). These features have rendered HIF- $1 \alpha$ as an attractive target for our study in inhibiting angiogenesis.

\section{TAM plus CXB lowers VEGF production in breast cancer cells}

We investigated the role of TAM and CXB in the inhibition of secretory VEGF, a pro-angiogenic factor responsible for the migration and invasion of breast cancer cells. VEGF secretion in serum-free culture conditioned medium was assessed in MCF7 and MDA-MB-231 cells by ELISA $24 \mathrm{~h}$ post-treatment. In both cell lines, TAM alone considerably upregulated VEGF secretion and the combination of CXB and TAM notably decreased VEGF secretion compared with no treatment (Figure 4A). Precisely, in control cells VEGF levels were found to be approximately 600 and $280 \mathrm{pg} / \mathrm{mL}$ in MCF7 and MDAMB-231 cells, respectively whereas CXB treatment alone does not showed any significant change in the secreted VEGF levels in both cell lines. However, induced VEGF was suppressed in combination treatment to $400 \mathrm{pg} / \mathrm{mL}$ in MCF7 and $190 \mathrm{pg} / \mathrm{mL}$ in MDA-MB-231 in comparison to TAM alone treated MCF7 (1000 pg/mL) and MDA-MB-231 (320 pg/mL).

\section{TAM plus CXB inhibits VEGF-mediated stimulation of VEGFR2 promoter activity}

To further confirm the role of enhanced activity induced by treatment with TAM and CXB in the transcriptional regulation of the VEGFR2 gene, cells were transiently transfected with a chimeric luciferase gene fused with the
5' region of the VEGFR2 promoter (Tischer et al., 1991), and the activity of the promoter was assayed in the presence and absence of VEGFR2 gene after treatment with the $\mathrm{IC}_{50}$ doses for $24 \mathrm{~h}$. Transfection induced VEGFR2 promoter activity in both MCF7 and MDA-MB-231 cells. To determine the relative fold change in VEGFR2 promoter activity, we normalized with respect to untransfected control (null) cells. VEGFR2 transfected untreated cell (UT) showed an approximately 3 - and 2-fold increase in promoter activity as compare to null in MCF7 and MDA-MB-231 cells, respectively. There was an approximately 1.2-fold increase in VEGFR2 promoter activity in TAM-treated and approximately 1.5 -fold increase in CXB-treated whereas fold increase was observed $<1$ in TAM-CXB treated with respect to null in both cell lines. Concisely, TAM and CXB was effective in blocking VEGFR2 promoter induced expression in MCF7 and MDA-MB-231 cells (Figure 4B). Taken together, the results of this experiment demonstrated that the activity of the VEGFR2 promoter is downregulated by $\mathrm{CXB}$ under the influence of TAM in both the cell lines. Besides, it also interferes with the phosphorylation of VEGFR2 (Figures 4C and 4D). Further, RT-PCR analysis was also in accordance with the VEGFR2 promoter luciferase activity (Figure 4E).

\section{TAM and CXB in combination suppress VEGFR2-mediated Src/STAT3/Akt/MAPK signaling}

VEGFR2 is the major receptor of VEGF in angiogenesis, and the VEGF/VEGFR2 pathway plays a central role in angiogenesis. TAM and CXB together strongly inhibited VEGF-activated VEGFR2 phosphorylation at Tyr1175 in western blotting analysis of MCF7 and MDA-MB-231 cells (Figures 4C and 4D). To determine whether this combination treatment could inhibit downstream signaling of VEGFR2, we screened some key factors involved in the VEGFR2 signaling pathway. Here, EGF was employed as a growth stimulant to induce phosphorylation levels of regulatory proteins. For both cell lines, the phosphorylation activities of Src and STAT3 were much lower with the combination than with either drug alone (Figures $4 \mathrm{C}$, 4D and Figure 5). Because STAT3 plays an important role as a critical transcription activator in angiogenesis, we then analyzed the expression of STAT3 downstream 
genes. Results showed that compared with TAM or CXB alone, TAM-CXB together inhibited the expression of anti-apoptotic Bcl-2 protein and increased the levels of pro-apoptotic Bax and Bak proteins (Figure 3E). STAT3 is also involved in the inhibition of apoptosis in endothelial cells. We found that various death substrates, such as poly (ADP-ribose) polymerase (PARP) (Figure 3E) and other molecules at conserved aspartic acid residues (data not shown), were more strongly activated by TAM-CXB in combination than by either drug alone in MCF7 and MDA-MB-231 cells. Taken together, these western blotting analysis results suggest that the combination of TAM-CXB blocks the VEGF-induced Src/STAT3 signaling pathway. Further, our western blotting analysis proved the involvement of VEGFR2 signaling in the inhibition of AKT and MAPK and the phosphorylation of the downstream protein Bad (Figure 5). Bad plays important roles in tumor cell function, angiogenesis, and tumor growth.

\section{TAM plus CXB causes significant inhibition of $\mathrm{S} 180$} tumors

We assessed the in vivo therapeutic efficacy of TAM and CXB in Swiss albino mice bearing S180 tumors. TAM and $\mathrm{CXB}$ each induced tumor regression and slowed tumor growth in these mice treatment groups (Figure 6A). Body weight of the animals was measured during the $7^{\text {th }}$ and $14^{\text {th }}$ day of treatment. Untreated mice and mice treated with TAM or with CXB gained weight over time; in contrast, whereas mice treated with both TAM and CXB maintained their weight (Figure 6B).

\section{CXB increases TAM-induced Splenocyte proliferation}

To assess the efficacy of TAM and CXB in modulating splenocyte proliferation, spleen cells of treated S180 mice were isolated and cultured in DMEM supplemented with $10 \%$ fetal bovine serum for $24 \mathrm{~h}$ and subjected to in vitro proliferation assays. Compared with untreated mice, mice treated with TAM, CXB, or both displayed approximately 1.5-, 1.2-, and 2.0-fold increases, respectively, in splenocyte proliferation (Figure 6C).

\section{Apoptotic effects of TAM and CXB on S180 tumor cells}

To assess the therapeutic efficacy of TAM and CXB, cells isolated from the intraperitoneally injected region of sacrificed mice were subjected to cell cycle analysis. Imprints of cytotoxic effects of these drugs were found at this region. The proportion of cells from untreated mice or mice treated with TAM, CXB, or both agents that was in the sub- $G_{1}$ phase was $0.07 \pm 0.56 \%, 2.8 \pm 0.16 \%, 1.55 \pm$ $0.84 \%$, and $3.69 \pm 0.63 \%$, respectively (Figure 6D). Ex vivo cell cycle studies showed analogous results $(4.61 \pm$ $0.27 \%, 29.06 \pm 0.13 \%, 17.52 \pm 0.77 \%$, and $51.67 \pm 0.34 \%$, respectively), to that of in vitro studies as shown in (Figure 6E) thereby confirming the additive therapeutic effect of the drugs.
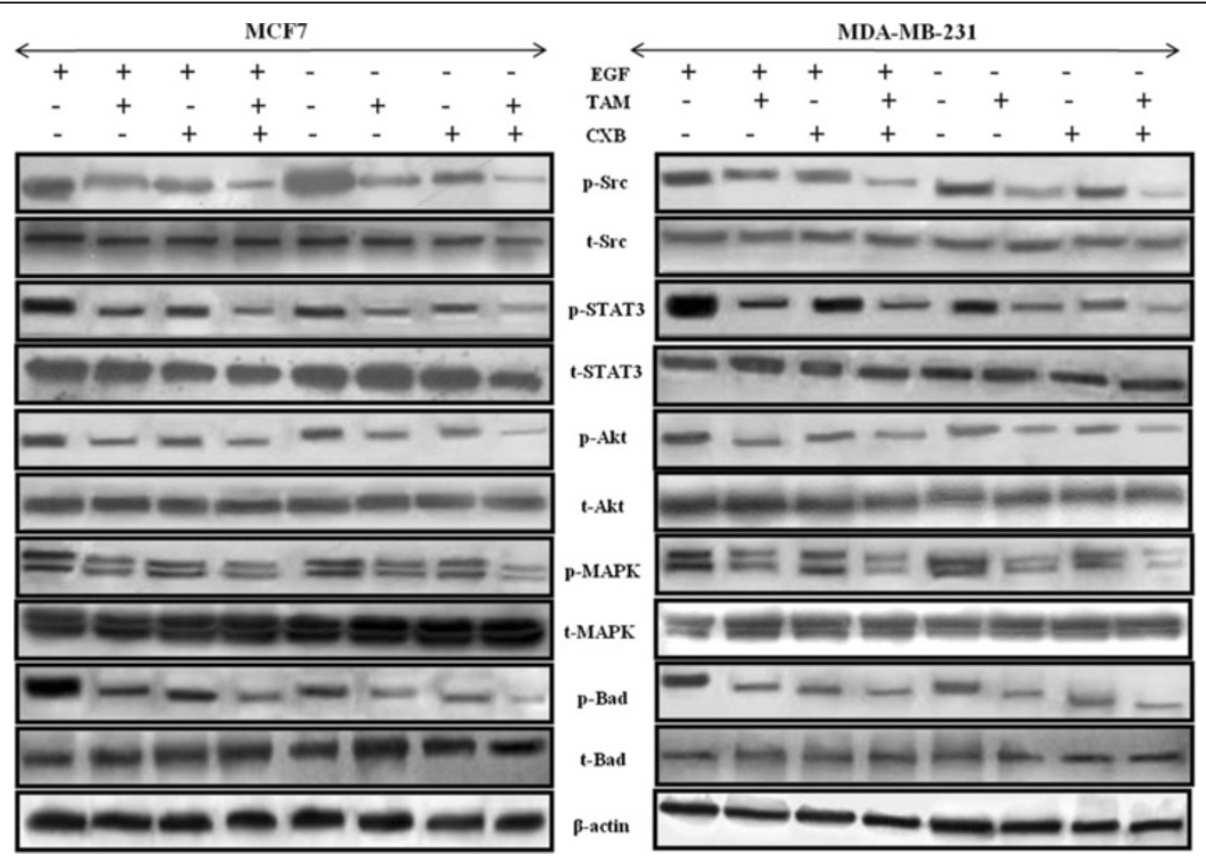

Figure 5 Phosphoprotein and total protein expression profiles of MCF7 (left) and MDA-MB-231 (right) breast cancer cells treated with TAM and/or CXB. Phosphorylated levels of p-Src (Tyr416), p-STAT3 (Tyr705), p-Akt (Ser473), p-MAPK (Thr202/Tyr204) and p-Bad (Ser136) were determined by western blot analysis using their specific antibodies. $\beta$-Actin was used as an invariant control for equal loading. 


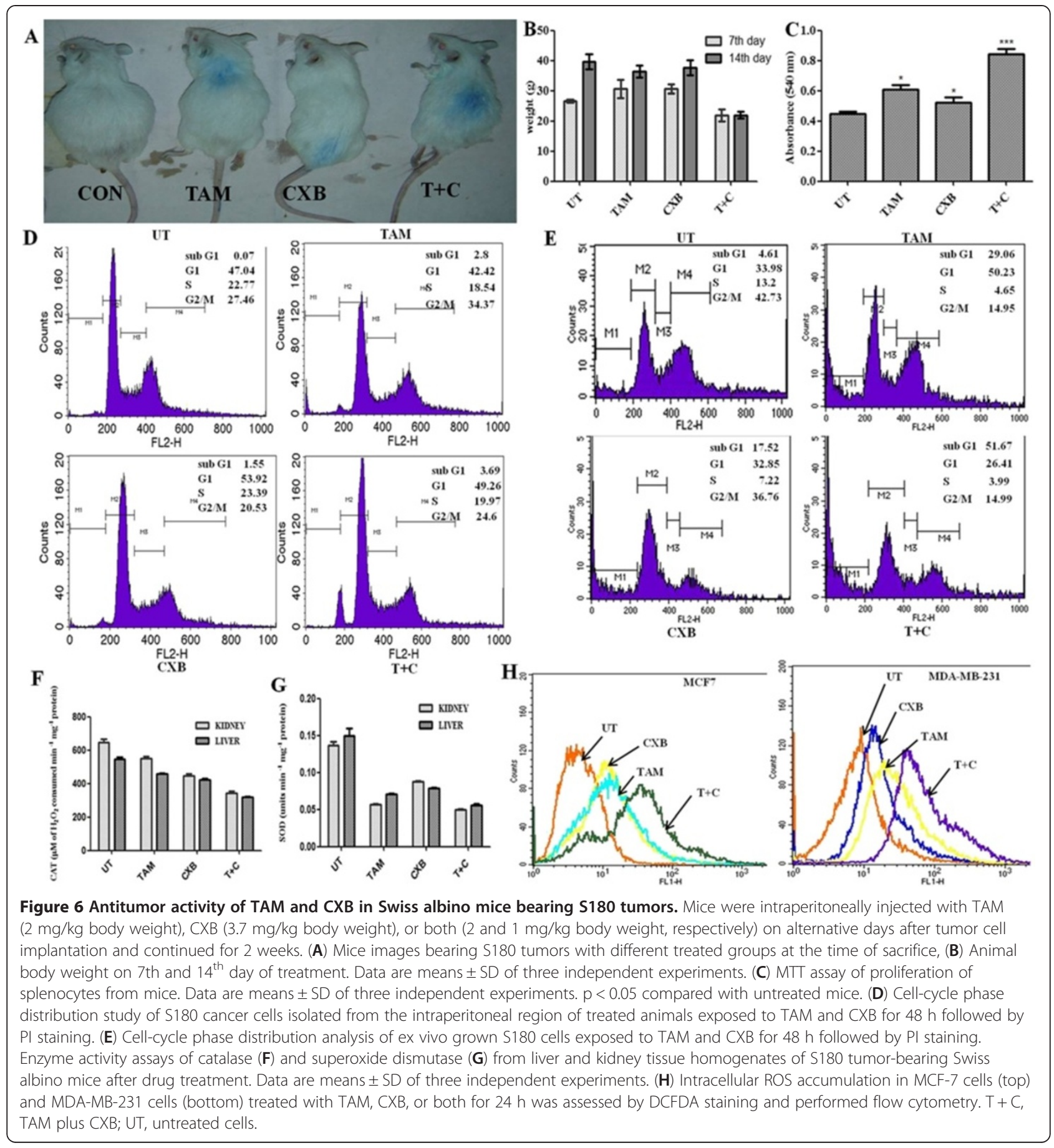

TAM and CXB additively decrease CAT and SOD activity CAT and SOD assays were performed to assess the role of reactive oxygen species in VEGF induction [46]. The activities of the antioxidant enzymes CAT and SOD in the liver and kidney of S180 tumor-bearing mice were assayed. For both TAM- and CXB-treated mice, the levels of CAT activity in liver tissue or in kidney tissue were significantly lower than those of untreated mice (Figure 6F). In addition, for mice treated with both TAM and CXB,
CAT activity in liver or kidney tissue was significantly lower than that in mice treated with TAM or CXB alone. Similar results were observed with SOD activity (Figure 6G).

\section{Role of ROS in the combined effect of TAM and CXB}

To establish whether treatment with TAM and CXB for $24 \mathrm{~h}$ induces ROS-dependent apoptosis, we investigated whether they increase ROS generation in MCF7 and 
MDA-MB-231 cells by measuring the intracellular levels of $\mathrm{H}_{2} \mathrm{O}_{2}$ using DCFDA staining. Flow cytometric analysis revealed that for both cell lines, TAM resulted in higher generation of ROS than CXB (Figure $6 \mathrm{H}$ ). In addition, treatment with both agents increased ROS production by over $50 \%$ as compared with the control cells, which was associated with enhanced apoptosis.

\section{Discussion}

TAM has been described as 'the most important drug developed in the history of breast cancer' [47]. The introduction of TAM heralded a new approach to the treatment of breast cancer. Initial clinical studies of TAM displayed its antiangiogenic and VEGF reducing ability in various tumor models [5,48-51]. Despite its meritorious stand in the treatment of breast cancer, prolonged administration of TAM causes intracellular VEGF levels to rise in patients, an undesirable response leading to enhanced metastasis and angiogenesis and resulting in inferior outcomes [14,52]. In addition, autocrine VEGF/VEGFR2 loop activation confers resistance to TAM in breast cancer cells [8]. In this perspective, we made an attempt to decrease intracellular VEGF levels by reducing the TAM dose in ER-positive and ERnegative breast cancer cells. For accomplishing the above goal we employed combination therapy by decreasing TAM dose and choose CXB, a selective COX-2 inhibitor as an adjuvant agent [53] that induces apoptosis through inhibiting angiogenesis by suppressing VEGF expression in gastric and breast cancers [20,54]. From the above report, in the current study we aimed to determine the expression profile of VEGFR2 and quantify VEGF in both MCF7 and MDA-MB-231 breast cancer cells treated with TAM, CXB or both. In our study, we observed reduction in VEGF levels in TAM and CXB treated MCF7 but no significant change in MDA-MB-231. Interestingly, we also found that the activity of VEGFR2 was inhibited by TAM and CXB in very low concentrations than either drug alone.

STAT proteins comprise a transcription factor family that participates in normal cellular events, such as proliferation, apoptosis and angiogenesis [55]. An increasing amount of evidence has suggested that STATs, mainly STAT3, play a critical role in angiogenesis. Indeed, activated STAT3 is a mediator and biomarker of VEGFinduced endothelial activation [56]. The VEGF/VEGFR2mediated STAT3 signaling pathway is a potential key target of anti-angiogenic tumor therapy $[57,58]$. Here, we elucidated the VEGFR2-activated STAT3 signaling pathway in human breast cancer cells. In our study, the activity of VEGFR2 was more strongly inhibited, and thus the activation of Src and STAT3 is suppressed by the combination of CXB and TAM (in very low concentrations) than either drug alone. The reduction of
STAT3 activation, in turn, inhibited the downstream gene expression of the anti-apoptotic Bcl-2 protein and increased the expression levels of the pro-apoptotic Bax and Bak proteins. Furthermore, the core proteins involved in apoptosis, including various death substrates such as PARP, were activated when treated with CXB and TAM in combination, which was consistent with the results of our apoptosis analysis.

VEGFR2 mediates Src regulation of endothelial cell junctions and vascular permeability $[59,60]$. Src proteins appear to be important for multiple aspects of tumor progression, including proliferation, disruption of cellcell contacts, migration and invasiveness [61]. TAM and $\mathrm{CXB}$ additively reduced tumor migration and invasion; this finding was supported by our wound-healing and Boyden chamber assay results. We also demonstrated that CXB and TAM in combination interfered with the binding of VEGF to VEGFR2, thus suppressing the phosphorylation of Src protein and contributing to antimetastatic activity leading to decreased MMP expression, as confirmed through the gelatin zymography and western blot analyses. Our study also showed that the ROS level decreased after co-administration of TAM and CXB confirmed through our FACS and in vivo studies.

Moreover, we proved the involvement of VEGFR2 signaling in the inhibition of Akt and MAPK molecules and in the phosphorylation of downstream proteins such as Bad and Bax, which play important roles in angiogenesis and apoptosis [24]. Supporting evidence concerning in vivo anti-angiogenic effects of TAM-CXB additively came from our chick embryonic CAM model and HUVEC-based tube formation assay with an in vitro model. All these results showed that treatment with both TAM and CXB suppressed the VEGFR2 pathways.

To thoroughly understand the extent of VEGF/ VEGFR2 inhibition by TAM and CXB in combination, we performed VEGFR2 overexpression studies through luciferase assays and quantified the serum VEGF secretion levels. Results showed an approximately 3- and 2fold increase in VEGFR2 promoter activity in transfected MCF7 and MDA-MB-231 cells, respectively. The observed VEGF-mediated up-regulation of VEGFR2 promoter activity in MCF7 and MDA-MB-231 cells was effectively suppressed by TAM and CXB in combination at very low concentrations ( $\mathrm{IC}_{50}$ values) as compared with either drug alone. Finally, to validate the extent of VEGFR2 expression at mRNA levels, we performed RTPCR studies and came up with similar results as the overexpression studies.

\section{Conclusion}

In summary, our study indicated that the combination of TAM and CXB at nontoxic levels exerts potent anti- 
angiogenic effects by specifically targeting VEGF/VEGFR2 autocrine signaling through ROS generation. This additive combination suggests an effective approach with promising results in anti-metastatic and apoptotic studies. In a line, our preclinical studies suggest that this combination is a potential candidate treatment against breast tumors expressing high levels of VEGF and VEGFR2.

\begin{abstract}
Abbreviations
TAM: Tamoxifen; CXB: Celecoxib; VEGF-A: Vascular endothelial growth factorA; VEGFR2: Vascular endothelial growth factor receptor 2; COX-

2: Cycloxygenase-2; DCFDA: 2',7'dichlorofluorescein diacetate; ROS: Reactive oxygen species; CAT: Catalase; SOD: Superoxide dismutase; RT PCR: Reverse transcriptase polymerase reaction; ER: Estrogen receptor; STAT3: Signal transducer and activator of transcription 3; MAPK: Mitogen-activated protein kinase; ELISA: Enzyme-linked immunosorbent assay; PARP: Poly(ADP-ribose) polymerase; HUVEC: Human umbilical vein endothelial cell; HIF-1a: Hypoxiainducible factor 1a; PI: Propidium iodide; DAPI: 4',6-diamidino-2-phenylindole; MTT: 3(4,5-dimethylthiazol-2-yl)-2,5 diphenyltetrazolium bromide; CBP: CREBbinding protein; VHL: von Hippel-Lindau tumor suppressor protein; MMP2: Matrix metalloproteinase2; CAM: Chorioallantoic Membrane.
\end{abstract}

\section{Competing interests}

No competing financial or personal interest in any company or organization is reported.

\section{Authors' contributions}

BNP, SR, MM conceived the study, designed the experiments, and drafted the manuscript. BNP and SR carried out the experiments. SD performed animal studies. KKD performed the RT-PCR studies. AP conducted VEGF quantification studies. AM and MM provided the critical revision of the manuscript. All authors read and approved the final manuscript.

\section{Acknowledgements}

B. N. Prashanth Kumar and Shashi Rajput are the recipients of a Research fellowship from the Council of Scientific and Industrial Research (CSIR), India. This study was supported by grants from the Department of Biotechnology (DBT: http://dbtindia.nic.in/index.asp), Council of Scientific and Industrial Research (CSIR: http://csirhrdg.res.in/) and Department of Science and Technology (DST: http://www.dst.gov.in/), India.

\section{Author details}

${ }^{1}$ School of Medical Science and Technology; Indian Institute of Technology Kharagpur, Kharagpur-721302, West Bengal PIN-721302, India. ${ }^{2}$ Department of Clinical Cancer Prevention, University of Texas MD Anderson Cancer Centre, Houston, TX, USA.

Received: 26 March 2013 Accepted: 31 May 2013

Published: 3 June 2013

\section{References}

1. Brauch H, Jordan VC: Targeting of tamoxifen to enhance antitumour action for the treatment and prevention of breast cancer: the 'personalised' approach? Eur J Cancer 2009, 45:2274-2283.

2. Cuzick J, Sestak I, Pinder SE, Ellis IO, Forsyth S, Bundred NJ, Forbes JF, Bishop $H$, Fentiman IS, George WD: Effect of tamoxifen and radiotherapy in women with locally excised ductal carcinoma in situ: long-term results from the UK/ANZ DCIS trial. Lancet Oncol 2011, 12:21-29.

3. Delozier T, Spielmann M, Mace-Lesec'h J, Janvier M, Hill C, Asselain B, Julien JP, Weber B, Mauriac L, Petit JC, et al: Tamoxifen adjuvant treatment duration in early breast cancer: initial results of a randomized study comparing short-term treatment with long-term treatment. Federation Nationale des Centres de Lutte Contre le Cancer Breast Group. J Clin Oncol 2000, 18:3507-3512.

4. Rajput S, Mandal M: Antitumor promoting potential of selected phytochemicals derived from spices: a review. Eur J Cancer Prev 2012, 21:205-215

5. McNamara DA, Harmey J, Wang JH, Kay E, Walsh TN, Bouchier-Hayes DJ: Tamoxifen inhibits endothelial cell proliferation and attenuates VEGF- mediated angiogenesis and migration in vivo. Eur J Surg Oncol 2001, 27:714-718.

6. Beck B, Driessens G, Goossens S, Youssef KK, Kuchnio A, Caauwe A, Sotiropoulou PA, Loges S, Lapouge G, Candi A, et al: A vascular niche and a VEGF-Nrp1 loop regulate the initiation and stemness of skin tumours. Nature 2011, 478:399-403.

7. Younes MN, Yigitbasi OG, Park YW, Kim SJ, Jasser SA, Hawthorne VS, Yazici YD, Mandal M, Bekele BN, Bucana CD, et al: Antivascular therapy of human follicular thyroid cancer experimental bone metastasis by blockade of epidermal growth factor receptor and vascular growth factor receptor phosphorylation. Cancer Res 2005, 65:4716-4727.

8. Aesoy R, Sanchez BC, Norum JH, Lewensohn R, Viktorsson $K$, Linderholm B: An autocrine VEGF/VEGFR2 and p38 signaling loop confers resistance to 4-hydroxytamoxifen in MCF-7 breast cancer cells. Mol Cancer Res 2008, 6:1630-1638.

9. Ryden L, Stendahl M, Jonsson H, Emdin S, Bengtsson NO, Landberg G: Tumor-specific VEGF-A and VEGFR2 in postmenopausal breast cancer patients with long-term follow-up. Implication of a link between VEGF pathway and tamoxifen response. Breast Cancer Res Treat 2005, 89:135-143.

10. Garvin S, Nilsson UW, Dabrosin C: Effects of oestradiol and tamoxifen on VEGF, soluble VEGFR-1, and VEGFR-2 in breast cancer and endothelial cells. Br J Cancer 2005, 93:1005-1010.

11. Qu Z, Van Ginkel S, Roy AM, Westbrook L, Nasrin M, Maxuitenko Y, Frost AR, Carey D, Wang W, Li R, et al: Vascular endothelial growth factor reduces tamoxifen efficacy and promotes metastatic colonization and desmoplasia in breast tumors. Cancer Res 2008, 68:6232-6240.

12. Lee JE, Chung KW, Han W, Kim SW, Kim SW, Shin HJ, Bae JY, Noh DY: Effect of estrogen, tamoxifen and epidermal growth factor on the transcriptional regulation of vascular endothelial growth factor in breast cancer cells. Anticancer Res 2004, 24:3961-3964.

13. Bogin L, Degani H: Hormonal regulation of VEGF in orthotopic MCF7 human breast cancer. Cancer Res 2002, 62:1948-1951.

14. Ruohola JK, Valve EM, Karkkainen MJ, Joukov V, Alitalo K, Harkonen PL: Vascular endothelial growth factors are differentially regulated by steroid hormones and antiestrogens in breast cancer cells. Mol Cell Endocrinol 1999, 149:29-40.

15. Hyder SM, Stancel GM, Chiappetta C, Murthy L, BoettgerTong HL, Makela S: Uterine expression of vascular endothelial growth factor is increased by estradiol and tamoxifen. Cancer Research 1996, 56:3954-3960.

16. Sanchez BC, Sundqvist M, Fohlin H, Spyratos F, Nordenskjold B, Stal O, Linderholm BK: Prolonged tamoxifen treatment increases relapse-free survival for patients with primary breast cancer expressing high levels of VEGF. Eur J Cancer 2010, 46:1580-1587.

17. Wu G, Luo J, Rana JS, Laham R, Sellke FW, Li J: Involvement of COX-2 in VEGF-induced angiogenesis via P38 and JNK pathways in vascular endothelial cells. Cardiovasc Res 2006, 69:512-519.

18. Hoeben A, Landuyt B, Highley MS, Wildiers H, Van Oosterom AT, De Bruijn EA: Vascular endothelial growth factor and angiogenesis. Pharmacol Rev 2004, 56:549-580.

19. Katharine Kirkpatrick WO: A. Elkak, Stephen Bustin PJ, Margaret Ghilchik and, Mokbel K: The mRNA Expression of Cyclooxygenase-2 (COX-2) and Vascular Endothelial Growth Factor (VEGF) in Human Breast Cancer. CURRENT MEDICAL RESEARCH AND OPINION 2002, 18:237-241.

20. Wei D, Wang L, He Y, Xiong HQ, Abbruzzese JL, Xie K: Celecoxib inhibits vascular endothelial growth factor expression in and reduces angiogenesis and metastasis of human pancreatic cancer via suppression of Sp1 transcription factor activity. Cancer Res 2004, 64:2030-2038.

21. Mikula-Pietrasik J, Kuczmarska A, Kucinska M, Murias M, Wierzchowski M, Winckiewicz M, Staniszewski R, Breborowicz A, Ksiazek K: Resveratrol and its synthetic derivatives exert opposite effects on mesothelial celldependent angiogenesis via modulating secretion of VEGF and IL-8 /CXCL8. Angiogenesis 2012, 15:361-376.

22. Dash R, Mandal M, Ghosh SK, Kundu SC: Silk sericin protein of tropical tasar silkworm inhibits UVB-induced apoptosis in human skin keratinocytes. Mol Cell Biochem 2008, 311:111-119.

23. Sarkar S, Mazumdar A, Dash R, Sarkar D, Fisher PB, Mandal M: ZD6474 Enhances Paclitaxel Antiproliferative and Apoptotic Effects in Breast Carcinoma Cells. J Cell Physiol 2011, 226:375-384.

24. Sarkar S, Mazumdar A, Dash R, Sarkar D, Fisher PB, Mandal M: ZD6474, a dual tyrosine kinase inhibitor of EGFR and VEGFR-2, inhibits MAPK/ERK 
and AKT/PI3-K and induces apoptosis in breast cancer cells. Cancer Biol Ther 2010, 9:592-603.

25. Tammali R, Reddy ABM, Srivastava SK, Ramana KV: Inhibition of aldose reductase prevents angiogenesis in vitro and in vivo. Angiogenesis 2011, 14:209-221

26. Mandal M, Myers JN, Lippman SM, Johnson FM, Williams MD, Rayala S, Ohshiro K, Rosenthal DI, Weber RS, Gallick GE, El-Naggar AK: Epithelial to mesenchymal transition in head and neck squamous carcinoma: association of Src activation with E-cadherin down-regulation, vimentin expression, and aggressive tumor features. Cancer 2008, 112:2088-2100.

27. Venkatesan P, Bhutia SK, Singh AK, Das SK, Dash R, Chaudhury K, Sarkar D, Fisher PB, Mandal M: AEE788 potentiates celecoxib-induced growth inhibition and apoptosis in human colon cancer cells. Life Sci 2012, 91:789-799.

28. Wang N, Wang ZY, Mo SL, Loo TY, Wang DM, Luo HB, Yang DP, Chen YL, Shen JG, Chen JP: Ellagic acid, a phenolic compound, exerts antiangiogenesis effects via VEGFR-2 signaling pathway in breast cancer. Breast Cancer Res Treat 2012, 134:943-955.

29. Santhekadur PK, Gredler R, Chen D, Siddiq A, Shen XN, Das SK, Emdad L, Fisher PB, Sarkar D: Late SV40 factor (LSF) enhances angiogenesis by transcriptionally up-regulating matrix metalloproteinase-9 (MMP-9). J Biol Chem 2012, 287:3425-3432

30. Koskimaki JE, Lee E, Chen W, Rivera CG, Rosca EV, Pandey NB, Popel AS: Synergy between a collagen IV mimetic peptide and a somatotropindomain derived peptide as angiogenesis and lymphangiogenesis inhibitors. Angiogenesis 2013, 16:159-170.

31. Chintharlapalli S, Papineni S, Ramaiah SK, Safe S: Betulinic acid inhibits prostate cancer growth through inhibition of specificity protein transcription factors. Cancer Res 2007, 67:2816-2823.

32. Shirakawa T, Gotoh A, Zhang Z, Kao C, Chung LW, Gardner TA: Development of human chorionic gonadotropin subunit-beta promoterbased toxic gene therapy for testicular cancer. Urology 2004, 63:613-618.

33. Domingues I, Rino J, Demmers JA, de Lanerolle P, Santos SC: VEGFR2 translocates to the nucleus to regulate its own transcription. PLoS One 2011, 6:e25668.

34. Levine JJ, Stimson-Crider KM, Vertino PM: Effects of methylation on expression of TMS1/ASC in human breast cancer cells. Oncogene 2003, 22:3475-3488

35. Venkatesan P, Puvvada N, Dash R, Kumar BNP, Sarkar D, Azab B, Pathak A, Kundu SC, Fisher PB, Mandal M: The potential of celecoxib-loaded hydroxyapatite-chitosan nanocomposite for the treatment of colon cancer. Biomaterials 2011, 32:3794-3806.

36. Das S, Dey KK, Dey G, Pal I, Majumder A: MaitiChoudhury S, kundu SC. Mandal M: Antineoplastic and apoptotic potential of traditional medicines thymoquinone and diosgenin in squamous cell carcinoma. PLoS One 2012, 7:e46641.

37. Yoshida S, Amano H, Hayashi I, Kitasato H, Kamata M, Inukai M, Yoshimura H, Majima M: COX-2/VEGF-dependent facilitation of tumor-associated angiogenesis and tumor growth in vivo. Lab Invest 2003, 83:1385-1394.

38. Kang HF, Wang XJ, Liu XX, Dai ZJ, Xue FJ: Xue XH: [Chemopreventive effect of tamoxifen combined with celecoxib on DMBA-induced breast cancer in rats]. Ai Zheng 2006, 25:1346-1350.

39. Majdalawieh AF, Hmaidan R, Carr Rl: Nigella sativa modulates splenocyte proliferation, Th1/Th2 cytokine profile, macrophage function and NK anti-tumor activity. J Ethnopharmacol 2010, 131:268-275.

40. Dhaunsi GS, Yousif MH, Akhtar S, Chappell MC, Diz DI, Benter IF: Angiotensin-(1-7) prevents diabetes-induced attenuation in PPARgamma and catalase activities. Eur J Pharmacol 2010, 638:108-114.

41. Marklund S, Marklund G: Involvement of the superoxide anion radical in the autoxidation of pyrogallol and a convenient assay for superoxide dismutase. Eur J Biochem 1974, 47:469-474.

42. Deryugina El, Quigley JP: Matrix metalloproteinases and tumor metastasis. Cancer Metastasis Rev 2006, 25:9-34.

43. Emdad L, Lee SG, Su ZZ, Jeon HY, Boukerche H, Sarkar D, Fisher PB: Astrocyte elevated gene-1 (AEG-1) functions as an oncogene and regulates angiogenesis. Proc Natl Acad Sci U S A 2009, 106:21300-21305.

44. Semenza GL: HIF-1 and tumor progression: pathophysiology and therapeutics. Trends Mol Med 2002, 8:S62-67.

45. Newcomb EW, Ali MA, Schnee T, Lan L, Lukyanov Y, Fowkes M, Miller DC, Zagzag D: Flavopiridol downregulates hypoxia-mediated hypoxiainducible factor-1alpha expression in human glioma cells by a proteasome-independent pathway: implications for in vivo therapy. Neuro Oncol 2005, 7:225-235

46. Kumar B, Gupta SK, Nag TC, Srivastava S, Saxena R: Green tea prevents hyperglycemia-induced retinal oxidative stress and inflammation in streptozotocin-induced diabetic rats. Ophthalmic Res 2012, 47:103-108.

47. Zheng J: Yao Z: [Effect of tamoxifen on apoptosis and drug resistance of breast cancer cells in vitro]. Zhonghua Zhong Liu Za Zhi 2000, 22:55-57.

48. Rajput S, Kumar BN, Sarkar S, Das S, Azab B, Santhekadur PK, Das SK, Emdad L, Sarkar D, Fisher PB, Mandal M: Targeted Apoptotic Effects of Thymoquinone and Tamoxifen on XIAP Mediated Akt Regulation in Breast Cancer. Plos One 2013, 8:e61342.

49. Marson LP, Kurian KM, Miller WR, Dixon JM: The effect of tamoxifen on breast tumour vascularity. Breast Cancer Res Treat 2001, 66:9-15.

50. Blackwell KL, Haroon ZA, Shan S, Saito W, Broadwater G, Greenberg CS, Dewhirst MW: Tamoxifen inhibits angiogenesis in estrogen receptornegative animal models. Clin Cancer Res 2000, 6:4359-4364.

51. Garvin S, Dabrosin C: Tamoxifen inhibits secretion of vascular endothelial growth factor in breast cancer in vivo. Cancer Res 2003, 63:8742-8748.

52. Adams J, Carder PJ, Downey S, Forbes MA, MacLennan K, Allgar V, Kaufman S, Hallam S, Bicknell R, Walker JJ, et al: Vascular endothelial growth factor (VEGF) in breast cancer: comparison of plasma, serum, and tissue VEGF and microvessel density and effects of tamoxifen. Cancer Res 2000, 60:2898-2905

53. Jeon YW, Suh YJ: Synergistic apoptotic effect of celecoxib and luteolin on breast cancer cells. Oncol Rep 2013, 29:819-825

54. Xu T, Wang NS, Fu LL, Ye CY, Yu SQ, Mei CL: Celecoxib inhibits growth of human autosomal dominant polycystic kidney cyst-lining epithelial cells through the VEGF/Raf/MAPK/ERK signaling pathway. Mol Biol Rep 2012, 39:7743-7753.

55. Zhang $X$, Song Y, Wu Y, Dong Y, Lai L, Zhang J, Lu B, Dai F, He L, Liu M, Yi $Z$ : Indirubin inhibits tumor growth by antitumor angiogenesis via blocking VEGFR2-mediated JAK/STAT3 signaling in endothelial cell. Int J Cancer 2011, 129:2502-2511.

56. Lu W, Chen H, Ye F, Wang F, Xie X: VEGF induces phosphorylation of STAT3 through binding VEGFR2 in ovarian carcinoma cells in vitro (vol 4, pg 363, 2006). Eur J Gynaecol Oncol 2006, 27:544-544.

57. Chen SH, Murphy DA, Lassoued W, Thurston G, Feldman MD, Lee WM: Activated STAT3 is a mediator and biomarker of VEGF endothelial activation. Cancer Biol Ther 2008, 7:1994-2003.

58. Bartoli M, Platt D, Lemtalsi T, Gu X, Brooks SE, Marrero MB, Caldwell RB: VEGF differentially activates STAT3 in microvascular endothelial cells. FASEB J 2003, 17:1562-1564.

59. Sun Z, Li X, Massena S, Kutschera S, Padhan N, Gualandi L, SundvoldGjerstad V, Gustafsson K, Choy WW, Zang G, et al: VEGFR2 induces c-Src signaling and vascular permeability in vivo via the adaptor protein TSAd. J Exp Med 2012, 209:1363-1377.

60. Meyer RD, Sacks DB, Rahimi N: IQGAP1-dependent signaling pathway regulates endothelial cell proliferation and angiogenesis. PLOS One 2008 3:3848.

61. Pohorelic B, Singh R, Parkin S, Koro K, Yang AD, Egan C, Magliocco A: Role of Src in breast cancer cell migration and invasion in a breast cell/bonederived cell microenvironment. Breast Cancer Res Treat 2012, 133:201-214.

doi:10.1186/1471-2407-13-273

Cite this article as: Kumar et al:: Celecoxib alleviates tamoxifeninstigated angiogenic effects by ROS-dependent VEGF/VEGFR2 autocrine signaling. BMC Cancer 2013 13:273. 